QUALITY

Volume 5, Nomor 1, 2017: 1-18

\title{
THE PARTNERSHIP MANAGEMENT OF PESANTRENS AND COMMUNITIES FOR THE INTEGRATED ECONOMIC AND EDUCATIONAL DEVELOPMENT
}

\author{
Asep Kurniawan \\ IAIN Syeh Nurjati Cirebon \\ asepqurniawan.ak@gmail.com
}

\begin{abstract}
Abstrak
Pesantren dan masyarakat harus dapat membangun manajemen kemitraan untuk tata pemerintahan yang baik dan kesejahteraan umum ekonomi dan pendidikan. Baru-baru ini, banyak pesantren, yang terlalu sibuk dengan kegiatan normatif daripada kegiatan sosial. Demikian pula, masyarakat saat ini lebih individualistis. Situasi ini tentunya menghambat pengelolaan kemitraan ini. Untuk itu pesantren harus berperan sebagai lembaga pemberdayaan masyarakat selain sebagai lembaga pemijatan dan pendidikan. Meski, pada intinya pesantren dan masyarakat bukan lembaga yang terpisah, karena keduanya saling membutuhkan dalam mewujudkan kemakmuran ekonomi dan pendidikan terpadu. Dengan demikian, mereka bisa membuat masyarakat sipil yang kuat.
\end{abstract}

Kata Kunci: Manajemen, Kemitraan, Ekonomi, Pendidikan

\begin{abstract}
Pesantrens and communities should be able to establish partnership management for good governance and the common welfare of the economy and education. Recently, many pesantrens, however, are too busy with normative activities than social activities. Similarly, recent society is more individualistic. This situation certainly inhibits this partnership management. For that pesantrens should play their role as institutions of community empowerment aside from being a massage and educational institution. Although, in essence, pesantrens and communities are not separated institutions, because, both of them need each other in achieving the integrated prosperity of economy and education. Thereby, they can make a strong civil society.
\end{abstract}

Key Words: Management, Partnership, Economy, Education

\section{A. Introduction}

The roles of mass organizations or non-governmental organizations are very important in achieving good governance and common prosperity. Many 
QUALITY

Volume 5, Nomor 1, 2017: 1-18

NGOs are the strength of the civil society as one of the actors in governance. One of the many religious-based NGOs is pesantren.

Discussing the role of the pesantren and its partnership with the communities is an attempt to realize good governance and social development. Therefore, it becomes an important and strategic role. In other words, in order to realize good governance, so it takes the participation of each element of governance in realizing mutual prosperity, including in this context is pesantren participation as part of civil society. It is called strategic role because pesantrens spread throughout Indonesia. It, proved, is capable of running a variety of roles in every development of the Indonesia.

Based on the Decision of the Fifth National Congress of Rabithah Ma'hadul Islamiah Number: 13/MukernasV/1996 on the "Declaration of Identity and Pesantren insights" stated that pesantren actually has three roles and functions are carried out simultaneously, imbued with the character of selfreliance, and the spirit of the struggle, namely:

1. As an educational institution and the development of Islamic teachings, pesantren should have a responsibility in educating the nation, reliable technology, and building a strong faith and piety.

2. As an Islamic institution, pesantren should have a responsibility to spread the Islamic religion, active in developing religious life, and improving society, nation and state inter-religious harmony.

3. As an the institutional development and community service, pesantren has a responsibility to perform its role in improving and strengthening community life, for the realization of equitable, civilized, prosperous and democratic Indonesian society based on Pancasila and the Constitution of 1945 (Siradj, et al, 1999).

The role played by the institution or organization is an affirmation of its functions to individuals or groups in the environment, such as the existence of pesantren in certain place can provide an important contribution to the society. This contribution is the embodiment of good partnership management between pesantren (Non Governmental/NGO) and community. So the role of pesantren 
QUALITY

Volume 5, Nomor 1, 2017: 1-18

can be an agent of chance for life in many ways, such as religious values, economy and others. Pesantren is essentially a multi-asset institution. Therefore, it has many functions, for example, pesantren as a traditional institution, which develops the function as a social institution and a religious mission (Horikoshi, 1987; Adrian Vickers, 2005). Meanwhile, Azyumardi Azra said that there are three functions of the pesantren, i.e. the transmission and the transfer of Islamic sciences, Islamic tradition maintenance, and reproduction of Islamic scholars (Nata, 2001).

The various elements of the missionary movement, non-governmental organizations (NGOs), and community grassroots should be encouraged to actively influence government and public policy (Jennifer Hsu, Reza Hasmath, 2014) to poverty reduction. One of its recommendations is local governments should build a partnership or design the program, which is synergistic with Islamic mass organizations and NGOs, so it build public communication between the stakeholders and the strength of collective work, with the spirit and the same orientation to poverty reduction and prosperity of the community (Peter Willetts, 2013). The conference declared that Islamic mass organizations are Islamic-based civil society has great potentials to encourage the creation and strength of good governance and social empowerment, but these potentials cannot be realized maximally. The great potentials are:

1. Islamic organizations have a broad reach and influence on the level of the grass roots.

2. Self-financing does not depend on government funding and foreign funding agencies.

3. Having a religious-social leverage that makes them have public credibility (Muwahidah \& Zakiyudin, 2007).

As already explained, pesantren, as a part of the actors in civil society and non-governmental organizations, should contribute to achieve a good governance. Pesantren with the development spirit is a concrete example of pesantren attempt, which does not only concentrate on developing the Islamic science, but also have a concern for the economic condition of the surrounding communities who made 
QUALITY

Volume 5, Nomor 1, 2017: 1-18

their living in the informal sector, such as small scale entrepreneurs, merchants, and farmers. This concern is a manifestation of the partnership management between educational institution (pesantren) and society.

However, there are opinions say that pesantrens, which exists today, are less able to perform their best roles both social role in society and their role in education. This opinion appears in the statement of Ronald Lukens-Bull, who said that many people are disappointed with the educational existence of pesantrens. This airing of cultural alienation opinion against pesantrens is a public assessment, which is actually not too far to the real conditions (2001).

It is confirmed by Azyumardi Azra (2005) who states that pesantrens reputation apparently questioned by some Indonesian Muslims. The majority of pesantrens today seem to be in an ivory tower, elitist, and far from social reality. This socialization and actualization problem compounded by scientific problems, namely a gap, alienation and differentiation between the Islamic worlds and the society.

Furthermore Azra (Muwahidah \& Zakiyudin, 2007) says that those problems are caused by:

1. Their traditional and conventional tendency to move more in message, education, social services (especially through hospitals and orphanages) rather than new fields, such as building good governance and eradicating poverty. They are criticized as having more "moral sensitivity" rather than "social sensitivity".

2. They are trapped in certain structural management, which makes them move slowly in the urgent current issues, so they are often left behind and late in respond.

3. They are often trapped in the routine programs, so that they lead to stagnation without any new breakthroughs, especially in advocacy programs for social empowerment.

The results of Murtadho's research states that most pesantrens, it seems, have two dominant paradigms. First, the paradigm of pesantrens is ulamaship institutions. In this context, pesantrens understood only as places of religion 
QUALITY

Volume 5, Nomor 1, 2017: 1-18

teaching and learning to produce prospective Muslim scholars (ulama) who eventually build society. Therefore, it is a naive view, if we say that the purposes of developing the pesantrens are not for the purposes of religious education, and ulamaship, for example, pesantrens for education of agriculture, animal husbandry and others. This understanding is still strongly dominates the view of most pesantrens (2012).

At a glance, the researchers find number of pesantrens, especially in West Java, do not contribute significantly yet to the economic progress of society. For example, in West Java, it may not only occur in that area or in many other areas, the existence of pesantrens does not give many contributions yet to the advancement of society. This is may be weird assumption, because the general assumption says that pesantrens activities do not build material, but build mental and spiritual development. However, sarcasm assumption could be presented again, as a religious educational institution; pesantrens should motivate people through religion not to be a backward society.

An ironic fact the impression in the preliminary study, the writer wants to express the religious phenomena associated with progress of economy and education in Indonesia. It has thousands of pesantrens, as many as 27230 pesantrens in Indonesia (Kementerian Agama RI, Pendidikan Agama Islam, 2012). If the number is devided by average number of sub-districts (6994 subdistricts), it will get the result of three or four pesantrens for one sub-district. A cursory impression with the total number of pesantrens, religion has not been able to develop society significantly. The people condition is still seem traditional and far from prosperity.

In aggregate of Indonesia society welfare is still far from the target of development, because of its achievements in the Human Development Index (HDI), measurement comparison of life expectancy, literacy, education, and living standard (A Davies and G. Quinlivan. 2006: 1), is 0.734 in 2007 or 111 world rank (one rank under Palestine). These conditions describe that, essentially, the conditions of Indonesia society welfare tends to a low level. The Patterns of the gap, based on this HDI main indicator, gives very different results with the pattern 
QUALITY

Volume 5, Nomor 1, 2017: 1-18

of the gap based on income per capita indicators. With a per capita income indicator the pattern of the gap in Indonesia during 1993-2012 was divergent (increasing) with high levels of gap also.

In addition to pesantrens, Indonesia has thousands of majlis taklim, which spread in every region, so that everybody can become an active member of 3-5 majlis taklim at once. The writer is stunned, why religion cannot promote progress in this area. Despite that pesantrens certainly cannot be blamed for granted with society backwardness, even though, there is the possibility of other factors, which cause such circumstance, for example, the impartiality central government's policy. But once again, why high levels of religiosity, religion is not able to advance the local community. In fact, the main Islam mission, as explained by the Prophet's hadeeth, is the religion of civilization builder to enhance civilized/ morals.

The noun of "civilized" is "civilization". The existence of pesantrens, as the religious learning institution in the process of this national modernization, is still in hidden places and like in the middle of the forest, and does not provide yet the benefits of a significant advance for the society. Religious teachings are presented to the people, precisely, means "the defeat". For example, patient in affliction, gratitude in pleasure even a little pleasure, and so on. Religion seemed to justify the defeats.

Meanwhile, an educational institution would be difficult to advance without the support of the community. Community contributions to educational institution is required, because they are (1) source supplier of students, teachers, funding, facilities, and others for organizing the educational institution, (2) the consumers of educational outcomes, which continuously follow and also influence the educational process, (3) participants of the educational process, which constantly follow and also influence the educational process (Asep Kurniawan, 2011). Thereby, what will happen to an educational institution, such as pesantrens, without the assistance and cooperation (partnership) with the communities?

Unfortunately, the symptoms of people care increasingly disappear. Otherwise, character of individual or selfishness of the public interest (E. 
QUALITY

Volume 5, Nomor 1, 2017: 1-18

Fernando M. Manullang, 2007: 110), recently, presumably increases. This is as proved in many studies, such as Hofstede and Hofstede (2005), Oyserman et al., (2002), Watson \& Morris, (2002), Voronov \& Singer, (2002) Darwish and Huber (2003), and others that the phenomena of individualistic life increase in many countries, including in Indonesia caused by the more population complexity, the economic tension, and advance technologies.

\section{B. Discussion}

\section{The Definitions}

Key words, which are in issue of this paper, are the partnership management of the pesantren and communities for the integrated economic and educational development. In etymology terms, management is defined as the work art done by other people. The meaning of this Mary Parker Follett's definition is a manager must organize and direct others to achieve organizational goals (Richard Barrett. 2003). Ricky W. Griffin defines management as a process of planning, organizing, coordinating, and controlling resources to achieve goals effectively and efficiently. Effective means that the goal can be achieved in accordance with the planning, and efficient means that existing task done correctly, organized, and accordance with the schedule (2012). Meanwhile, partnership means a group of people or institutions who agree to work together to advance their common interests. Thereby, partnership management is a process of planning, organizing, coordinating, and controlling resources to achieve goals effectively, efficiently, and jointly carried out by a number of people or institutions in one team.

Pesantren (pondok pesantren) is a two term denoting one meaning. Pesantren essentially is religious institutions that provide education, develop, and spread Islamic knowledge and common knowledge to the students. Whereas pondok means house or residence for students (Nasir Ridwan, 2005; Zamakhsari Dhofir, 1982; Ronald Lukens-Bull. 2005).

The term "society" came from the Latin word "societas", which in turn is derived from the noun "socius" ("comrade, friend, ally"; adjectival form 
QUALITY

Volume 5, Nomor 1, 2017: 1-18

socialis) used to describe a bond or interaction between parties that are friendly, or at least civil. Without an article, the term can refer to the entirety of humanity (also: "society in general", "society at large", etc.), although those who are unfriendly or uncivil to the remainder of society in this sense may be deemed to be "antisocial". Adam Smith wrote that a society "may subsist among different men, as among different merchants, from a sense of its utility without any mutual love or affection, if only they refrain from doing injury to each other (Asa Briggs, 2000).

Empowerment is the development process where people take the initiative to start the process of social activities to improve the situation and condition they have (James A. Christenson, et al, 1989). Therefore, development of economy and education in an integrated manner is a developmental process where the administrators take the initiative to start the social activities to improve economy and education they have in an integrated manner.

\section{The Functions of Pesantren in the Communities}

Pesantren function in society as follows (Asep Kurniawan, 2011):

A. As an agent of change; this introduces various changes in knowledge, ways of thinking, living patterns, customs and procedures of the association, and so on. As an agent of change, educational institution should be more forward the role and functions, especially in developing potential, to changes thinking and behavior in accordance with the applicable standard norms. So if people are in violation of these terms, then there are two questions presented, whether this agent is not successful in educating the public or those that are hard to be educated.

b. As an agents of selection; this selects society according to their abilities, potentials, and develop them maximally. Educational institution should be able to choose society diverse potential. This requires special skills, of course, especially for the educational manager, so that the potential of society, in this case is student, can be developed optimally.

c. As an agent of development; this helps to improve society's welfare and 
QUALITY

Volume 5, Nomor 1, 2017: 1-18

reduces or eliminates their class differences.

d. As an agent of assimilation; this seeks to reduce or eliminate the differences on the basis of traditions, customs and culture.

e. As an agent of preservation; this maintains and continues the good cultural.

f. As an agent of class leveling; this increases the social level of students.

\section{The Functions of Communities in Pesantren}

Pesantren is from and for communities. It is a social institution organized and owned by the community. Pesantren must meet the communities' needs and funded by them directly or indirectly. Therefore, Pesantren is part of the overall system of communities' lives.

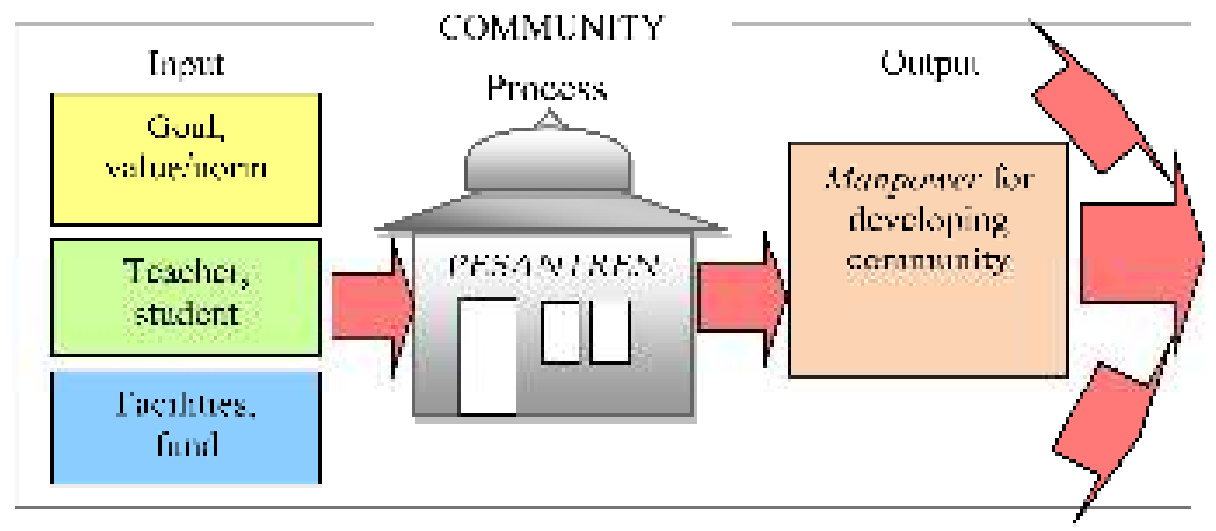

Figure 1

The Functions of Communities in Pesantren

(Source: Asep Kurniawan, 2011:114)

Based on the overall system, community is:

1. Source suppliers, which provides students, teachers, others for holding pesantren.

2. Consumers, pesantren output continuously follow and influence the educational process.

The importance of the communitie's role as a "participant in the process" is still less recognized by teacher of pesantren. Because of the important role of community as a "participant in the process", so pesantren should invite them to participate in more educational activities and more use of existing resources in 
QUALITY

Volume 5, Nomor 1, 2017: 1-18

the communities.

We can distinguish the resources of society, as follows (Asep Kurniawan, 2011):

1. Human resources: the prominent / influential, scholars, experts with particular skills, the generous, and so on. They can help and participate in the educational process of pesantren.

2. Social resources: formal and informal groups or organizations, with various norms, rules and habits that influence the educational process of pesantren.

3. Cultural and religious resources with different values of life, traditions, teachings, culture and the arts enrich education in pesantren.

4. Physical environment resources: nature can be used in education of pesantren.

5. Material and financial resources that come formally from government and informally from community.

\section{The Meaning of Partnership Management}

Pesantren, as a social institution organized and owned by the communities, must meet the needs of the communities. It has a legal and moral obligation to provide information of the objectives, programs, needs and circumstances to the public. It also should know clearly needs, expectations and demands of society.

Today, there is an increasingly widespread assumption that pesantrens cannot adapt to society changes, i.e. it is "left behind" in development. Pesantrens are also considered too "progressive", so they cannot be followed and cannot be understood by the communities. As though, there is "a gap" between pesantrens and communities. Pesantrens can no longer help to improve and develop society.

Cannot pesantrens follow the development of the communities? Or are not they followed by the communities? This still needs a thorough investigation. Explicitly, pesantrens and communities should have mutual understanding.

So, in this case, it needs school public relation, that has some functions as 
QUALITY

Volume 5, Nomor 1, 2017: 1-18

follow:

1. Developing public understanding of all implementation aspects of the pesantrens.

2. Setting communities' expectations to pesantrens.

3. Obtaining sufficient support from the communities, such as financial, material and moral.

4. Having a greater responsibility on the quality of public education that can be provided by pesantrens.

5. Realizing the necessary changes and acquiring facilities in realizing them.

6. Involving the communities in solving the educational problems.

7. Increasing the spirit of cooperation between pesantrens and communities and increasing leadership participation in improving communities' lives.

\section{The Partnership Management Principles of Pesantren and Communities}

There are a number of principles that need to be considered in order to develop an pesantren and communities partnership management, namely:

1. Integrity, namely the relationship between the leadership of pesantren and communities is a single entity. This principle implies that all school and community activities must be integrated. In a sense, pesantren inform academic and non-academic activities to the communities in an integrated manner.

2. Continuity, namely a continuous development process. Pesantren or communities should provide continuous information. Communities help pesantren through public-opinion in order to keep a good public image. Partnership management of the pesantren and communities should be carried out continuously, or it is not done at any time, for example, only once in a year or in a semester / quarter, or at the time of asking for financial assistance to parents / community.

3. Coverage, namely pesantren conveys the facts to the public as a whole. Thus, all aspects of pesantren life considered, such as religious and economic life. Therefore, every activity can be explained through mass media, pesantren newspapers, newsletters, and so on. Reports activities 
QUALITY

Volume 5, Nomor 1, 2017: 1-18

should be comprehensive and cover all aspects / factors or substances that need to be communicated and known by the public, for example, extracurricular, curricular, remedial teaching, etc. This principle also implies that all the information should be complete, accurate and up to date.

4. Simplicity, namely information is simple. The information is a sense of friendship and easy words. In essence, it is easy to understand.

5. Constructiveness, namely information can make a positive public opinion towards pesantren.

6. Adaptability, namely pesantren program should pay attention and adapt to the surrounding communities.

7. Flexibility, namely program at any time able to accept the changes (Sahertian, 1994).

\section{The Partnership Management of Pesantrens and the Communities For the}

\section{Integrated Economic and Educational Development}

The partnership management of pesantrens and communities is a process of participatory interaction as the substance of the educational management expansion, because it has a great impact on the substance of the core educational management. With the increasing number of people's demands for educational services, some substantive aspects of this needs to be organized in order to contribute to the success of educational management core (Imron, 2003; Patil, 2012).

The substance of the other existence of educational managements is time management, conflict management, change management, school culture management, communication management, group dynamics management, and information system management. The core educational management substances are: curriculum and learning management, classroom management, human resource management, student management, infrastructure management, and financial management (Imron, 2003). The role of educational institutions is an affirmation of the agency functions for individuals and groups in their environment. Such as, the existence of pesantrens in certain place will make an important contribution to the surrounding communities. 
QUALITY

Volume 5, Nomor 1, 2017: 1-18

In the partnership context of pesantrens and the community, Nandika (2005) argues that the pesantrens, as educational institutions owned by the communities, has the potential to be developed into a center of human resource development (HRD) towards the realization of national welfare. Pesantrens are considered to have grounded nature and strong social institution and represents the aspirations of the majority of the surrounding communities. Pesantrens are considered to have potential to act as a strategic regional development center.

Pesantrens, as parts of civil society (as an educational institution, the massage institution, empowerment and communities service agency), develop their roles in empowering the communities' economy. This functionalization is evidence that participation is needed in achieving good governance and the main goal of regional autonomy, i.e. the independence of region and communities. Pesantrens role development in empowering people is one of the important efforts to strengthen the communities role in development, because the government still faces many cultural, structural problems and the private sector that tends to deviate to earn unilateral advantages.

In development, empowerment is a relevant approach to strengthen civil society. This empowerment is very concerned with the active participation of the communities (mutual cooperation) with the opportunity to develop economy and education they need. In this case, local government is required to utilize various potentials, strengths and participation in the communities. Moreover, with limited resources, the power and participation of the communities, especially NGOs (Non Governmental Organizations) is needed in this empowerment. One of the NGOs, the most potential to play a role in empowering communities, is pesantren. Pesantren, which is commonly known as a traditional Islamic educational institution declares as a concerned citizen's institution.

Pesantrens, which are spread throughout Indonesia including remote rural areas, are potential in empowering society's economy and education. Economic and educational activities of pesantrens, which is basically to facilitate service's independence (both for internal and community), is a 
QUALITY

Volume 5, Nomor 1, 2017: 1-18

developed large capital in empowering community's education and economy. Moreover, with its strength as an organization that has strong integrity and availability resources, it will be able to be the massive and more productive basis of society's economic and educational empowerment.

Pesantren essentially is a multi-asset institution. Because of that, it has many functions. Horikoshi, for example, argues that pesantren is a traditional institution that serves as a social and religious massage institution (Horikoshi, 1987). Meanwhile, Azyumardi Azra says that there are three functions of the pesantren; function of transfer and transmission, Islamic sciences, Islamic tradition maintenance, and reproductive scholars (Abudin Nata, 2001).

These functions are to build students' character. It is composed of three interrelated parts, namely: moral knowing, moral feeling, and moral behavior. Good character consists of knowing the good, desiring the good and doing the good. In this case, it requires habits of the mind, habits of the heart, and habits of the action (Zubaedi 2011).

Further the description of pesantren functions is stated by Nur Syam. According to him, pesantren is a religious institution that plays function as a social institution. It includes: (1) as a source of values and morality, (2) as a deepening of values and religious teachings, (3) as controllers and filters of moral and spiritual life, (4) as an intermediary for the society development, and (5) as a practical source of life. In other writings, Nur Syam also says that pesantren function is community development agent (Nur Syam, 2005). In this paper, pesantren, as an agent of empowerment, is more focused on the economy and education.

Pesantren, with the spirit of empowerment, is one concrete example of pesantren efforts, which not only concentrates on developing the Islamic sciences, but also concerns for the economic condition of surrounding community. Generally, they work in the informal sector, such as; small entrepreneurs, traders, breeders and farmers. This condition, of course, need to be responded and answered intelligently and responsibly by pesantren. If not, it will lose relevance in the role and function of social dynamics. Currently, there 
QUALITY

Volume 5, Nomor 1, 2017: 1-18

are enough examples of pesantren concern in empowering surrounding communities' economy and education. The active involvement of pesantren in empowering communities' economy is pesantren commitment to the surrounding communities in improving their ability individually and in groups. It is intended to achieve the level of optimal human resources, so that it can improve the communities' self-reliance-based welfare. Here, it's clear that pesantren actually provides the "blessing" of the surrounding communities.

In connection with the conditions described above, pesantren needs to change continuously along with the communities' demands as a consequence of the dynamics of social change. As an experienced institution of education and "religious communities" development, pesantren should not ignore the changing demands. Although its basic philosophy (to educate the religious beliefs - based community self-reliance) is still adhered, but with the society rapid changes in today's global era, pesantren needs to adapt with those changes especially in its management (Nur Syam, 2005).

\section{Conclusion}

Pesantren and communities are not separated institutions, because both of them need each other in achieving the integrated economic and educational prosperity. Pesantren functions in society are agent of change, selection, development, assimilation, preservation, and class leveling. Instead, communities' functions for pesantren are the source of human, social, culture, religion, physical environment, material and finance.

For that, they can cooperate for their advancement of the integrated economy and education, because economy will not progress without education. Similarly, education will not progress without economy. Moreover pesantren's position, as non-governmental organizations, should adapt to social changes.

Pesantren, as part of civil society, develops its role (as an educational institution, massage institution, empowerment and community service agencies) in empowering communities' economy and education. This functionalization is participation that needed so much in achieving good governance and the main 
QUALITY

Volume 5, Nomor 1, 2017: 1-18

goal of local autonomy, i.e. the local and communities independence.

\section{REFERENCES}

Azra, Azyumardi. (2005). "Kata Sambutan", in Jamaluddin Malik (ed.), Pemberdayaan Pesantren Kebudayaan: Menuju Kemandirian dan Profesionalisme Santri dengan Metode Daurah. Yogyakarta, Pustaka Pesantren.

Barrett, Richard. (2003). Vocational Business: Training, Developing and Motivating People. Cheltenham, United Kingdom: Nelson Thornes.

Briggs, Asa. 2000. The Age of Improvement. 2nd ed. Harlow: Longman.

Bull, Ronald Lukens-, (2001), "Two Sides of the Same Coin: Modernity and Tradition in Indonesian Islamic Education," in Anthropology and Education Quarterly. 32(3). Arlington County, Virginia, U.S.: the American Anthropological Association.

Christenson, James A., Jerry W. Robinson, Jr Ames (editors). (1989). Community Development in Perspective. Ames, Iowa, United States: Iowa State University Press.

Darwish, A.E. and Huber, G.L. (2003). Individualism vs Collectivism in Different Cultures: A Cross-Cultural Study” In Intercultural Education. 14, 147-55.

Davies, A. and G. Quinlivan. (2006). "A Panel Data Analysis of the Impact of Trade on Human Development", in Journal of Socioeconomics. 35(5). Amsterdam, Netherlands: Elsevier Inc.

Dhofir, Zamakhsari. (1982). Tradisi Pesantren: Studi tentang Pandangan Hidup Kiai. Jakarta: LP3ES.

Griffin, Ricky. (2012). Management. Boston, Massachusetts: Cengage Learning.

Hofstede, G. and Hofstede, G.J. (2005). Cultures and Organizations: Software of the Mind. New York: McGraw-Hill.

Horikoshi, H. (1987). Kiai dan Perubahan Sosial, translated by Umar Balasain, et al. Jakarta: P3M.

Hsu, Jennifer, and Reza Hasmath. (2014). "The Local Corporatist State and NGO Relations in China", in Journal of Contemporary China 23 (87). London, United Kingdom: Routledge.

Imron, Ali, (2003). "Manajemen Pendidikan Substansi Inti dan Eksistensi" dalam Ali Imron, et al. (ed.). Manajemen Pendidikan Analisis Substantif dan Aplikasinya dalam Institusi Pendidikan. Malang: Universitas Negeri Malang. 
QUALITY

Volume 5, Nomor 1, 2017: 1-18

Kementerian Agama RI, Pendidikan Agama Islam. (2012). Analisis dan Interpretasi Data pada Pondok Pesantren, Madrasah Dinyah (Madin), Taman Pendidikan Qur'an (TQ) tahun pelajaran 2011-2012. Jakarta: Kementerian Agama RI, Pendidikan Agama Islam

Kurniawan, Asep. (2011). Manajemen Pendidikan di Sekolah. Cirebon: Nurjati Press.

Manullang, E. Fernando M.. (2007). Menggapai Hukum Berkeadilan: Tinjauan Hukum Kodrat dan Antinomi Nilai. Jakarta: Penerbit Buku Kompas.

Murtadho, M. (2012). Pesantren dan Pemberdayaan Ekonomi. Jakarta: Badan Litbang Depag RI.

Muwahidah, Siti Sarah dan Zakiyudin Baidhowy (editor). (2007). Islam, Good Governance, dan Pengentasan Kemiskinan: Kebijakan Pemerintah, Kiprah Kelompok Islam, dan Potret Gerakan Inisiatif di Tingkat Lokal. Jakarta: Ma'arif Institute for Culture and Humanity.

Nandika, Dodi. (2005). Pesantren Sebagai Basis Pembangunan Wilayah. (Online) Tersedia:

http://www.republika.co.id/kolomdetail.asp?id=188820\&kat $\mathrm{id}=6$. Oktober 2007).

Nata, Abuddin (ed.). (2001). Sejarah Pertumbuhan dan Perkembangan Lembagalembaga Pendidikan Islam di Indonesia. Jakarta: Grasindo.

Oyserman, D., Coon, H.M., and Kemmelmeier, M. (2002). "Rethinking Individualism and Collectivism: Evaluation of Theoretical Assumptions and Meta-analysis", in Psychological Bulletin, 128 (1), 3-72. Washington, D.C., United States: American Psychological Association.

Ridwan, Nasir. (2005). Mencari Tipologi Format Pendidikan Ideal, Pondok Pesantren di Tengah Arus Perubahan. Yogyakarta: Pustaka Pelajar.

Sahertian, Piet A. (1994). Dimensi-dimensi Administrasi di Sekolah. Surabaya: Usaha Nasional. Sutisna, Oteng. 1985. Administrasi Dasar Teoritis untuk Praktek Profesonal. Bandung: Angkasa.

Siradj, et al. (1999). Pesantren Masa Depan: Wacana Pengembangan Transformasi Pesantren. Bandung: Pustaka Hidayah.

Syam, Nur. (2005). "Pengembangan Komunitas Pesantren, dalam Moh Ali Aziz, dkk. (ed.). Dakwah Pengembangan Masyarakat: Paradigma Aksi Metodologi. Yogyakarta: Pustaka Pesantren.

Voronov, M., and Singer, J.A. (2002). "The Myth of Individualism-Collectivism: A Critical Review", in The Journal of Social Psychology, 142, 461-480. Philadelphia, USA: Taylor \& Francis formerly Heldref Publications.

Watson, P.J., \& Morris, R.J. (2002). "Individualist Collectivist Values: Hypotheses Suggested by Alexis de Tocqueville", in The Journal of 
QUALITY

Volume 5, Nomor 1, 2017: 1-18

Psychology, 136, 263-271. Philadelphia, USA: Taylor \& Francis formerly Heldref Publications.

Willetts, Peter. (2013). "What is a Non-Governmental Organization?", in The Hague Journal of Diplomacy. 8. Dutch: Koninklijke Brill NV, Leiden.

Zubaedi. (2011). Desain Pendidikan Karakter Konsepsi dan Aplikasinya dalam Lembaga Pendidikan. Jakarta: Kencana. 